\title{
Connecting into the Social Sustainability Effects of Infrastructure through China's Digital Silk Road: Issues, Indices, and Indications
}

\author{
Jean-Marc F. Blanchard ${ }^{1, *}$ and Bas Hooijmaaijers ${ }^{2,3}$ \\ 1 Mr. \& Mrs. S.H. Wong Center for the Study of Multinational Corporations, Los Gatos, CA 95032, USA \\ 2 School of Advanced International and Area Studies, East China Normal University, Shanghai 200062, China; \\ bas.hooijmaaijers@kuleuven.be \\ 3 Leuven International and European Studies Institute, KU Leuven, 3000 Leuven, Belgium \\ * Correspondence: executive_director@mnccenter.org
}

Citation: Blanchard, J.-M.F.; Hooijmaaijers, B. Connecting into the Social Sustainability Effects of Infrastructure through China's Digital Silk Road: Issues, Indices, and Indications. Sustainability 2021, 13, 12739. https://doi.org/10.3390/ su132212739

Academic Editor: Marc A. Rosen

Received: 31 August 2021

Accepted: 9 November 2021

Published: 18 November 2021

Publisher's Note: MDPI stays neutral with regard to jurisdictional claims in published maps and institutional affiliations.

Copyright: (c) 2021 by the authors. Licensee MDPI, Basel, Switzerland. This article is an open access article distributed under the terms and conditions of the Creative Commons Attribution (CC BY) license (https:// creativecommons.org/licenses/by/ $4.0 /)$.

\begin{abstract}
There is a heated debate about the social-sustainability implications of infrastructure. We engage this debate by delving into China's Digital Silk Road (DSR), an important component of China's infrastructure-centric Belt and Road Initiative (BRI). Optimists and pessimists have offered strong views about the DSR's social-sustainability implications. Unfortunately, there is a dearth of analytical tools and in-depth studies which can be used to judge their competing arguments. In this article, we address these problems in two ways. First, we advance an original scheme for operationalizing social sustainability. Second, we use our framework to systematically analyze the DSR's social-sustainability effects in Ethiopia, Malaysia, the United Arab Emirates, and Hungary. Our research indicates that much of the positive and negative commentary about the DSR's social-sustainability implications is problematic. None of our cases show significant year-to-year changes in political or quality-of-life social-sustainability benchmarks. Indeed, our analysis indicates that analysts must pay close attention to the political and economic context to understand the social-sustainability patterns associated with DSR infrastructure. Finally, it suggests that the social-sustainability implications of DSR infrastructure are dependent on its scale and nature. These findings have ramifications for broader debates about the socioeconomic impact of infrastructure.
\end{abstract}

Keywords: infrastructure; Digital Silk Road; Belt and Road Initiative; social sustainability; China; Ethiopia; Hungary; Malaysia; United Arab Emirates

\section{Introduction}

There is a heated debate about the social-sustainability implications of infrastructure. This also is the case with respect to China's Digital Silk Road (DSR), an important component of China's infrastructure-heavy Belt and Road Initiative (BRI). Studying the DSR, therefore, provides a window into the socioeconomic consequences of infrastructure. Many in the West see the DSR, detailed below, as disastrous for social-sustainability facets like democracy, freedom, and participation. Among other things, they opine the DSR and associated Chinese technologies could foster "a dystopian, Orwellian society" (aka digital totalitarian society) pervaded by extensive surveillance and exacerbate the risks of censorship, the leakage of personal data, and political repression [1-3]. In contrast, proponents see China's scheme as advancing social sustainability by breaking down the "digital divide", helping to reduce crime and corruption, and improving access to healthcare. Aside from these prospective gains, the DSR will spur growth and job gains, upgrade the technological level of developing countries, and help solve environmental problems [2,4-7].

The existing literature on the DSR is extensive and growing. However, it is not particularly helpful in illuminating the actual ramifications of DSR infrastructure for social sustainability, which consists of a plethora of political and quality of life (QOL) considerations that we detail more extensively below. One notable shortcoming of the literature is 
its tendency to equate headlines about projects with actual projects or to exaggerate the implications of these projects, defects present in the larger BRI literature [8]. A second is the absence of analytical frameworks that can be used to measure social-sustainability trends. A third is that evaluations of the DSR's social-sustainability consequences frequently treat positive and negative effects in isolation from one another, leading to one-sided assessments or prognostications. A fourth is the failure to assess if the DSR really caused the negatives or positives correlated with it or whether contextual factors might have produced witnessed outcomes. A fifth is that the literature often lacks case studies or comparative analysis, though there are some exceptions, albeit imperfect ones [9]. A sixth is that, even when there are "case studies", they often are unsystematic or lack depth.

There are multiple reasons to be attentive to the social-sustainability implications of DSR infrastructure, especially at a time when business, countries, and societies are digitalizing because of competitive pressures, the desire to industrialize/move up the value-added chain, and changes forced by the global COVID pandemic [10]. From an academic vantage point, the study of the DSR can enrich our understanding of the potential social-sustainability costs and benefits of infrastructure. Importantly, it also can reveal the conditions under which these costs and benefits obtain. Aside from this, it can shed light on the social-sustainability implications of China's BRI and, relatedly, its overseas investment and infrastructure activities. With respect to policymaking, research on the DSR can illuminate if all the hype about the DSR's adverse social-sustainability effects truly is warranted. As for businesses, analysis is germane given the pressures they face to reduce their negative impacts on society. Research on the consequences of the DSR for social sustainability can further highlight opportunities for businesses to enhance the good implications of DSR infrastructure or counter the negative outcomes associated with it.

To analyze the social-sustainability implications of DSR infrastructure, we undertook a systematic, comparative analysis of four DSR infrastructure country cases-we studied Ethiopia, Malaysia, the United Arab Emirates/UAE, and Hungary for reasons detailed in our methodology section below-using an original scheme for measuring social sustainability. Our article makes a number of methodological and empirical contributions. As for methodological contribution, it advances a novel framework for measuring social sustainability. Second, it rebuts the absolutist positions of the optimists and pessimists towards the DSR. It evidences that there almost uniformly are no notable changes in the political or QOL aspects of social sustainability following the introduction of the DSR. Third, it reveals that one can rarely make a clear, causal connection between changes in social-sustainability indices and DSR infrastructure. Indeed, other factors like domestic political trends in DSR participants such as Ethiopia and Hungary seem far more potent drivers of observed trends. Fourth, it demonstrates that DSR infrastructure's social-sustainability effects relate to the scale and nature of DSR infrastructure (e.g., fintech versus telecommunications). Fifth, the scale and scope of DSR infrastructure are often more limited than presumed.

This article consists of eight parts. The second (next) section gives background information about the DSR, such as its history and features. The third part represents our methodology section. It not only conceptualizes social sustainability but also discusses how we measure the impact of the DSR on social sustainability. The fourth through seventh sections consist of our case studies. The eighth part constitutes our conclusion. It summarizes our piece, highlights our key findings and future research directions, and offers some concluding remarks.

\section{Connecting into the DSR: A Primer and Critique}

The DSR entered the public consciousness in 2015 with the promulgation of China's authoritative March 2015 "Vision and Actions on Jointly Building Silk Road Economic Belt and 21st Century Maritime Silk Road" [11] (p. 6). In 2016, China's State Council (Cabinet) issued a national plan for informatization, which spoke about the DSR. The next year, Chinese President Xi Jinping highlighted features of the DSR at the first Belt and Road Forum in Beijing. Since then, China has signed formal agreements relating to the DSR 
with various countries such as Bangladesh, Czech Republic, Hungary, South Korea, and the UAE. It also has promoted the DSR at various international venues such as the World Internet Conference, meetings between the Chinese government and various regional organizations, and meetings with national leaders [12].

It is hard to pin down the DSR because there are no public plans or documents enumerating a DSR project list, identifying the DSR's objectives, or discussing the process for implementing the DSR [9] (p. 3). Nevertheless, it is clear from government statements, media reports, memorandum of understanding (MoUs), scholarly treatments, and think tank analyses that the DSR is the more digitally oriented part of the BRI and encompasses a plethora of information and communication technology (ICT) infrastructure. Examples of DSR technology, which can be found in Ethiopia, Germany, Malaysia, Pakistan, and Poland, include broadband networks, fiber optic cables, data centers, e-commerce, fintech, and safe and smart cities. Some even deem autonomous vehicles, logistics centers, and software gaming companies part of the DSR [11] (pp. 8-9), [13] (p. 48), [7,14].

Due to the aforementioned absence of a public materials on DSR projects, it is near impossible to provide definitive, comprehensive information on the aggregate volumes of DSR projects globally or regionally, their geographic distribution, or their sectoral (e.g., cloud computing versus fintech) distribution. According to the consultancy RWR Advisory Group, the greatest amounts of DSR money went to India, Mexico, Malaysia, the Philippines, and Ethiopia [15]. Using the respected American Enterprise Institute China Global Investment Tracker (AEI CGIT), it appears that DSR-related foreign direct investment (FDI) runs $\$ 17.2$ billion for the period 2015 to 2020 , while DSR contracting totals roughly $\$ 3.7$ billion over the same span of time. AEI CGIT data also indicate that the three biggest recipients of DSR-related FDI were the UK, India, and Italy, while the three largest destinations for DSR contracting were Italy, Cameroon, and Myanmar. Ultimately, the best assessment requires the aggregation of data built from a review of DSR FDI and contracting on a country-by-country basis. These data lacunae only serve to validate the need for the kind of case study work performed herein.

Academic researchers, business commentators, and pundits have proffered various views about the DSR's political and economic objectives, both domestic and international. We initially discuss the DSR's putative economic aims. First, the DSR allegedly is a mechanism for China to promote growth and move up the value chain. Second, it is a way for China to advance in areas like AI, cloud computing, 5G, quantum computing, satellites, and smart cities. Third, it will facilitate the internationalization of Chinese technology companies and afford them new business prospects ranging from contracting to design and engineering services to hardware sales to hardware maintenance. Relatedly, it will increase the prominence of Chinese technology and technical standards, which will boost the market shares and profit-making opportunities of Chinese companies. Fourth, it will facilitate the internationalization of China's currency, the renminbi (RMB) and provide Beijing with independence from the US-dominated global payments system. Lastly, digital infrastructure will become increasingly centered around China to the benefit of China and Chinese companies [1,16,17], [18] (pp. 2, 5-6), [13] (pp. 24-25, 49).

Turning to political rationales, the DSR supposedly is a manifestation of China's desire to become a digital superpower with a leading role in creating the future ICT order [11] (p. 5-6), [1] (p. 1). This is a matter of prestige. It also is about gaining independence from the Western-dominated technological order by attaining a cutting-edge position in hardware, software, and services, which, in turn, advances Chinese goals such as protecting national sovereignty and national security $[11,16,19]$. Pessimists charge that the DSR will diminish the freedom of other regions, countries, and companies by making them dependent upon Chinese technologies and infrastructure, giving Beijing control over large quantities of information, and ensnaring them in Chinese e-commerce and payment systems [18] (pp. 2, 6, 9), [13] (p. 14), [16]. It has even been posited that DSR infrastructure helps China challenge Washington indirectly [18] (p. 1). One way is by offering a technological alternative. Another is by laying various pathways for China to promote its preferred 
governance norms for cyberspace, which stress the primacy of the state, strong national sovereignty, and the state's right to monitor, filter, and restrict data flows [18] (p. 10), [20]. Relatedly, some contend Beijing is exploiting the DSR to ensconce digital authoritarianism or an illiberal political model around the globe [18] (p. 2), [13] (p. 49), [3,16,20].

Aside from the Chinese government, there are a wide variety, in terms of size, ownership (public or private), and business lines, Chinese companies involved in the DSR. Beijing supports Chinese DSR players, both public and private, and their projects with subsidies, loans, massive research and development (R\&D) funding, free land, immense spending on ICT-related infrastructure inside China, protected home markets, and diplomatic support [7,11,16,21,22]. Some of the well-known Chinese firms involved in the DSR include Alibaba, Ant Financial, China Mobile, Dahua, Huawei, Hikvision, Inspur, NucTech, Transsion, and ZTE [12].

We noted earlier that the DSR raises notable social-sustainability issues. To elaborate, one issue is that DSR infrastructure will facilitate mass surveillance and control. Another is that participant countries will use DSR technologies to spy on political opponents, suppress political activities, and repress dissent, which actually transpired in Ethiopia, Uganda, and Zambia. Another is that the DSR will facilitate censorship [1,3,16,23]. As one very negative assessment put it, DSR infrastructure opens the door to the institutionalization of unlawful surveillance, suppression of human rights, and downfall of democratic values. It may also perpetuate the rule of authoritarian regimes and become a tool of oppression against minorities or political opponents [13] (p. 52). In this vein, it is not encouraging that Chinese companies are some of the biggest exporters of AI-surveillance technologies, such as cameras, recognition systems, and data processing and that many DSR safe and smart city customers are governments ranking partly free or not free. Moreover, DSR players and Beijing are training others on how to build surveillance states and control information flows [11] (pp. 14, 26), [13] (pp. 14, 50), [3].

Beyond the DSR's potential implications for democracy, individual freedoms, and participation, many are anxious about the privacy implications of the DSR given the extensive involvement of Chinese companies in critical infrastructure such as cloud computing, data centers, and e-government. Pessimists raise the alarm that DSR infrastructure may afford Chinese companies, their government clients (which may be authoritarian or repressive regimes), and perhaps even the Chinese government (given the legal and political constraints under which Chinese companies operate) access to sensitive individual health, financial, legal, voting, tax, and travel information through various hardware and software backdoors or taps that might exist in cables, data centers, and satellite systems, among others $[3,16,18,24,25]$.

There are three general problems with the aforementioned debates about the DSR's implications. One is that there is a lack of analytical tools to measure the outcomes associated with DSR infrastructure. Another is that neither the optimists nor pessimists systematically analyze the validity of their arguments. A third is that both camps typically present unbalanced assessments. Naysayers, for example, ignore the fact that DSR infrastructure can have positive social-sustainability implications. To illustrate, the DSR can enhance digital connectivity by providing digital infrastructure. It further can help reduce inequality between and within countries by reducing the digital gap between developing and developed countries, expanding the digital resources of small- and medium-sized enterprises, and increasing access to education and health care services [11] (p. 14). Aside from this, the DSR has the potential to, in concept, reduce crime, increase government efficiency, and drive improvements in QOL, e.g., by reducing traffic congestion. To be balanced, any assessment of the DSR should take into account such positive externalities.

\section{Methodology and Materials}

In this section, we begin with a brief treatment of the concept of sustainability, subsequently engaging the narrower concept of social sustainability. After addressing these critical conceptual issues, we then present our original operationalization scheme for mea- 
suring the impact of infrastructure, specifically DSR infrastructure, on social sustainability. We next explain the rationale for our case study selections before concluding with an enumeration of some of the materials we used to execute our case studies.

Despite decades of use, sustainability has no clear definition. Most treatments start with the well-known 1987 Brundtland Commission definition: development that "meets the needs of the present without compromising the ability of future generations to meet their own needs" [26] (p. 22). There, obviously, are many ambiguities here, such as whose "needs" and the meaning of the term "needs", and one can question if this conceptualization lacks ambition [27] (pp. 368-369), [28] (p. 1080), [29]. While the preceding conceptualization does not have an obvious environmental bias to it, the vast majority of works on sustainability concentrate on environmental issues [26,30,31]. With the passage of time came increased attention to economic and social sustainability. Sustainability ultimately came to be understood as the trinity of three interlinked realms-environment, economic, and social; planet, profits, and people; or the Triple-Bottom Line [26,32-35]. To note this, however, hardly clarifies the delimitation of these realms, their connections with one another, the populations to which they apply, the costs and benefits they encompass, or the timeframes over which they should be evaluated [36] (p. 193), [29,32]. Part of the problem relates to the customary vagueness of social concepts like "justice", "leadership", or "revolution". Another is that the term "sustainability", which is always en vogue, has been hijacked to advance multiple agendas, and this has diluted whatever clarity it had, if any [34] (pp. 140-144). Another is that many treat the concept in a very unfocused way rather than proffering useful analytical schemes. While accepting that it is difficult to conceptualize sustainability and its components, we find suggestions to "fuhgeddaboudit" or to do it through a process of community deliberation unhelpful or unrealistic [29]. There are those that need a working scheme for evaluation, comparison, and other purposes.

As one might expect, given the preceding discussion, the concept of social sustainability also is vague [37] (p. 183). It has become a catchall phrase for almost every kind of social-justice concern. Unfortunately, many have very unclear or tenuous links to sustainability. Illustrative social-sustainability definitions include the ability of society "to sustain and reproduce itself at an acceptable level of functioning in terms of social organization" [38] (p. 68), "a quality of society that encourages durable circumstances for human well-being, particularly for susceptible persons or groups" [39] (p. 328), and growth that "nurtures a favorable environment for the compatible cohabitation of different groups" while "improving the quality of life (QOL) for all" [37] (p. 184). Regardless, conventional practice involves defining social sustainability in terms of a "laundry list". These lists include QOL objectives, such as poverty alleviation, equal distribution of goods and services, good governance, safety, transport, and employment conditions. They also include amorphous end goals, such as equality, community, democracy, participation, and cultural life [26,38-42]. Despite their tenuous link to sustainability, their ambiguities, and the difficulties of measuring-much less gathering data for-them, these lists can be a useful starting point for an operationalization scheme. Such a scheme must take into account the context, as some have argued [28]. In more concrete terms, it needs to focus on what is relevant, given we are analyzing DSR infrastructure. For instance, it is unlikely the DSR could meaningfully exacerbate or alleviate poverty. In contrast, it is quite possible that the DSR could affect democracy negatively or participation opportunities positively. Beyond this, an operationalization scheme should pay attention to items that can be comprehended and reliably measured, for which data are available, and that can be used across multiple cases [27] (p. 372). Given the above, we consider the following aspects of social sustainability: democracy, freedom, participation, good governance, transportation, safety, health, and access to communication.

We now turn to our operationalization scheme. To gauge our metrics (some of which are "composite" variables or variables which themselves are a function of other variables), we advocate using, to the extent possible, single and easy to understand quantitative indexes from reputable sources that are likely to provide comparable data on a large 
number of countries. In many instances, however, it may be necessary to exploit multiple and/or qualitative indexes because that is what is available, needed to provide sufficient geographic coverage, or yields the desired quality of information. Table 1 below lists our social-sustainability benchmarks, the variables that comprise them (if relevant), and the primary and secondary sources that supply data for the metric.

Table 1. Social-sustainability operationalization scheme [43-57].

\begin{tabular}{|c|c|c|c|}
\hline Metric & Components & Preferred Data Source & Alternative Data Source \\
\hline Democracy & $\mathrm{N} / \mathrm{A}$ & $\begin{array}{l}\text { Freedom House "Freedom in } \\
\text { the World" (FITW) Report [43] }\end{array}$ & $\mathrm{N} / \mathrm{A}$ \\
\hline \multirow{3}{*}{ Freedom } & Surveillance & $\begin{array}{c}\text { Top Surveillance Cities } \\
\text { Worldwide [44] }\end{array}$ & \multirow{3}{*}{$\begin{array}{c}\text { Human Rights Watch country } \\
\text { reports [49] }\end{array}$} \\
\hline & Privacy rights & $\begin{array}{l}\text { Privacy International and } \\
\text { Electronic Privacy } \\
\text { Information Center }[45,46]\end{array}$ & \\
\hline & Censorship & $\begin{array}{l}\text { Reporters without Borders } \\
\text { "World Press Freedom Index" } \\
\text { (WPFI) and Freedom House } \\
\text { "Freedom on the Net" (FOTN) } \\
\text { Report }[47,48]\end{array}$ & \\
\hline Participation & $\mathrm{N} / \mathrm{A}$ & $\begin{array}{l}\text { Organization on Economic } \\
\text { Cooperation and } \\
\text { Development (OECD) Better } \\
\text { Life Index [50] }\end{array}$ & $\begin{array}{l}\text { FITW Report "Political } \\
\text { Pluralism and Participation" } \\
\text { (the sum of criteria B1, B3, } \\
\text { and B4) }\end{array}$ \\
\hline Good governance & Government effectiveness & $\begin{array}{l}\text { World Bank “Government } \\
\text { Effectiveness" [51] }\end{array}$ & $\mathrm{N} / \mathrm{A}$ \\
\hline Transportation & Traffic Congestion & TomTom Traffic Index [52] & $\mathrm{N} / \mathrm{A}$ \\
\hline \multirow[t]{2}{*}{ Safety } & $\begin{array}{l}\text { Serious crimes (serious } \\
\text { assaults, robbery) }\end{array}$ & \multirow{2}{*}{$\begin{array}{c}\text { United Nations Office on } \\
\text { Drugs and Crime (UNODC) } \\
{[53]}\end{array}$} & \multirow[t]{2}{*}{$\mathrm{N} / \mathrm{A}$} \\
\hline & Property crimes (burglary) & & \\
\hline \multirow{3}{*}{ Health } & $\begin{array}{l}\text { Infant Mortality Rate } \\
\text { Probabilities [54] }\end{array}$ & \multirow{3}{*}{$\begin{array}{c}\text { World Health Organization } \\
\text { (WHO) "The Global Health } \\
\text { Observatory" }\end{array}$} & \multirow{3}{*}{$\mathrm{N} / \mathrm{A}$} \\
\hline & $\begin{array}{c}\text { Demand for Family Planning } \\
\text { Satisfied [55] }\end{array}$ & & \\
\hline & $\begin{array}{l}\text { Estimated Road Traffic Death } \\
\text { Rate (per 100,000) [56] }\end{array}$ & & \\
\hline \multirow{4}{*}{ Access to communications } & $\begin{array}{c}\text { Fixed Broadband } \\
\text { Subscriptions (per 100) }\end{array}$ & \multirow{4}{*}{$\begin{array}{c}\text { World Bank Open } \\
\text { Data-Infrastructure [57] }\end{array}$} & \multirow{4}{*}{$\mathrm{N} / \mathrm{A}$} \\
\hline & $\begin{array}{l}\text { Fixed Telephone Subscriptions } \\
\text { (per 100) }\end{array}$ & & \\
\hline & $\begin{array}{l}\text { Mobile Cellular Subscriptions } \\
\text { (per 100) }\end{array}$ & & \\
\hline & $\begin{array}{l}\text { Secure internet servers } \\
\text { (per million) }\end{array}$ & & \\
\hline
\end{tabular}

None of these metrics is perfect, but they have the advantages of being comprehensible, accessible, replicable, applicable to multiple cases, and/or possessing clear links to the DSR, our objective of study.

For our analysis, we chose Ethiopia, Malaysia, UAE, and Hungary as our case studies for various reasons. First, all are involved in the DSR as evidenced by formal agreements, explicit commentary from political leaders or government officials, and/or other credible evidence. Second, all host a diversity of DSR projects. If there were only one type of DSR 
project (e.g., cloud computing), this might limit the generalizability of our findings. Third, all have been involved in the DSR for several years, allowing us to analyze the socialsustainability impact of DSR infrastructure over time. Fourth, these countries are diverse in terms of geography, political regime, and development level. If the same findings appear across these diverse cases, then the generalizability of these findings increases. Lastly, it is possible to obtain materials on the DSR in these countries and their social-sustainability effects, albeit with limits. As for research stages, in each case study, we initially overview the relevant country's political and economic relations with China. We then describe the DSR infrastructure in the relevant country. Using our measurement scheme, we next present information on social sustainability from the year before the DSR began in the relevant country to the latest year possible. Finally, we contemplate the extent to which the DSR actually caused any changes in these indicators.

Our case studies draw upon a variety of primary and secondary source materials. Regarding primary sources, we used data prepared by international governmental organizations, such as the World Bank and WHO, and government statements, particularly, but not just for our social-sustainability analysis. Turning to secondary sources, we use newspaper articles, think tank studies, scholarly articles and books, reports by credible nongovernmental organizations such as Freedom House, and expert blogs. All our materials are English-language materials, but it should be noted that some (e.g., think-tank reports) have been translated into English by the relevant entity (e.g., an in-country think tank) or written by analysts, observers, or reporters present in the relevant case-study country.

\section{Results}

\subsection{Ethiopia}

\subsubsection{Ethiopia-China Relations Overview}

Bilateral relations took off in the mid-1990s, with Ethiopia maintaining close relations with China thereafter for diverse reasons. As for political reasons, Ethiopia's rulers want to fend off Western governance and human rights demands, strengthen their domestic position, and bolster their country's military. With respect to economic reasons, Ethiopia covets China as a trade, infrastructure, and technology partner, source of capital, and development model. For its part, China has embraced Ethiopia because of the latter's central location in the Horn of Africa, its heavyweight status in East Africa and Africa, and its willingness to support China with words and deeds in international organizations and elsewhere. Ethiopia has had economic appeal given its market size, growth rate, role as a transit point into the interior of Africa, and resource endowments [58] (pp. 83-85).

In 2006, China became Ethiopia's largest trade partner [59] (p. 156). Merchandise trade increased from $\$ 97.67$ million to $\$ 163.07$ million between 2000 and 2018 [60]. For a long time, there were no meaningful Chinese outward FDI (OFDI) flows to Ethiopia. This changed after 2000, with China eventually becoming Ethiopia's major inward FDI source [61] (pp. 9-11). Annual Chinese OFDI flows to Ethiopia hit $\$ 140$ million in 2010, $\$ 350$ million in 2016, and \$320 million in 2020 [62]. Chinese contracting dwarfs Chinese OFDI (COFDI). Prior to the BRI, Ethiopia awarded billions of dollars in contracts to Chinese firms to build power projects and transportation infrastructure [62]. Aside from the above, China has lent Ethiopia billions [63]. Ethiopia was one of the earliest African countries to sign BRI cooperation documents and has been quite enthusiastic about it because BRI transportation infrastructure improves its connectivity. For their part, BRI industrial parks and special economic zones fuel Ethiopian growth, create jobs, boost exports, advance industrialization, and increase tax revenues while BRI power projects charge up Ethiopia's industrialization, export, and modernization drives [64-66].

\subsubsection{The DSR in Ethiopia}

It is reasonable to treat Ethiopia as a DSR country because in meetings, China and Ethiopian leaders have highlighted the DSR as an area of cooperation that should be strengthened [67]. In addition, Chinese technology firms such as Inspur, which are in- 
volved in the DSR as businesses and members of DSR bodies, have explicitly stated the intent to carry out DSR projects in Ethiopia [68]. Moreover, Ethiopia-China ICT/S\&T cooperation emphasizes projects-satellites-that are part of the DSR. Beyond this, knowledgeable commentators treat Ethiopia as a DSR participant [69-71]. One set of DSR projects includes an $\$ 8$ million remote sensing satellite (launched in 2019), along with an associated command and control facility, as well as an image satellite (launched in 2020), and a planned communication and broadcast satellite and planned satellite data-receiver station [71-73]. Another is a Huawei smart city contract [74]. Another is Alibaba's e-commerce platform, known as the electronic World Trade Platform (eWTP). This venture, set forth in three MoUs signed in 2019, encompasses the creation of a digital trade hub, training programs, and regulatory reforms [75]. Many have raised fears about the DSR potential adverse implications for social sustainability in Ethiopia because, inter alia, the Ethiopian government may exploit the DSR to increase domestic surveillance [69-71].

\subsubsection{The DSR's Implications for Social Sustainability in Ethiopia—Political Aspects}

As we note in our methodology section, we use the Freedom House FITW report to evaluate "democracy" trends [43]. Examining the period 2017 to 2020 (the most recent year for which data are available), the FITW report ranks Ethiopia 12 out of 100 in 2017 for reasons such as a lack of free and fair elections, limits on political rights, and poor government transparency, 19 out of 100 in 2018 largely for the same reasons, 24 out of 100 in 2019 (though there were improvements in areas like election quality and political rights), and 22 of 100 in 2020. The score for 2020 showed a slight decline from 2019 because of increased domestic political repression.

To reiterate, we measure "freedom" by looking at surveillance data, privacy rights, and censorship. As for surveillance, our data source indicates that surveillance cameras, in terms of number and geographic density, in Addis Ababa (Ethiopia's largest city in terms of population), are few. Regarding privacy rights, we were not able to find any systematic treatments of the situation in Ethiopia. With respect to censorship, we drew upon the Reporters without Borders (RSF) WPFI and the Freedom House FOTN report. According to RSF WPFI, Ethiopia ranked 110 out of 180 in 2019, 99 out of 179 in 2020, and 101 in 2021 [48]. The FOTN report ranks Ethiopia 14 out of 100 in 2017 because of government interference with communication systems, limits on content, and violations of user rights, 17 out of 100 in 2018 due to some improvements in access and content restrictions, 28 out of 100 in 2019 due to major improvements in access and some improvements in content restrictions; and 29 out of 100 in 2020 due to some improvements in access, undercut slightly by content restrictions [47]. The FOTN report designates Ethiopia as "not free" every year [47].

As for "participation", the OECD Better Life Index does not provide information for Ethiopia, so we turned to the FITW report, which evaluates whether or not the public and minority (not just ethnically defined) populations have political participation opportunities in terms of the right to organize and freedom from obstruction by non-political system actors (FITW report criteria B1, B3, and B4) [43]. For 2017, Ethiopia garnered 0 out of 12 possible points due to problems relating to participation in all these areas. In 2018, its score increased to 2 out of 12 due to improvements in organization opportunities and for minority populations, moved up to 4 out of 12 in 2019 due to improvements in organization opportunities, and declined to 3 out of 12 in 2020 due to changes in organization opportunities.

Our final political metric is "government effectiveness". According to the World Bank's Government Effectiveness database, which provides information on Ethiopia until 2019, Ethiopia's government effectiveness is far below the world median. It received a score of -0.70 in 2017, -0.61 in 2018, and -0.63 in 2019 (the highest potential score is 2.5). 


\subsubsection{The DSR's Implications for Social Sustainability in Ethiopia-QOL Aspects}

For the period 2017 to 2020, the TomTom Traffic Index does not provide traffic congestion data for any cities or regions in Ethiopia or the country as a whole. We thus are unable to provide information about traffic congestion patterns.

As for crime data, the UNODC does not provide data for Ethiopia for any of the metrics (violent crimes, such as serious assault; and property crimes, such as burglary) that we wanted to study. The data situation with respect to health is only slightly better. WHO data indicate that Ethiopia's infant mortality rate probability dropped from 41.24 in 2016 to 39.49 in 2017 to 37.38 in 2018 to 36.55 [54]. With respect to Demand for Family Planning Satisfied, the WHO only provides data for 2016 (pre-DSR in Ethiopia), and thus the data are not useful for our study. This is also the case with respect to data on road-traffic injuries and deaths; that is, the data are only reported for 2016.

The World Bank does not provide data for fixed broadband subscriptions per 100 people for Ethiopia. The data on fixed telephone subscriptions per 100 people (and mobile cellular subscription per 100 people) for Ethiopia, unfortunately, end in 2017 and thus terminate too early to be of use for our analysis. The data, though, do show a dramatic increase in secure internet servers per 1 million people from 150 or so in 2019 to around 650 secure internet servers per 1 million people in 2020 [76].

\subsubsection{Assessment}

If we look at the social-sustainability situation in Ethiopia, political indicators show fluctuations, even though, in an absolute sense, they are consistently disheartening. After the start of the DSR, we see improvement in democracy rankings between 2017 and 2019, with a slight decline in 2020 (this said, all Ethiopia's scores are so low that Freedom House deems it "not free" for all the years during our study). As for "freedom", trends are similar. There are some improvements in terms of censorship trends and surveillance does not seem to have become notably worse. Even so, Ethiopia's censorship patterns remain quite poor. "Participation" data reflect a positive trend, with some backtracking in 2020, though there are severe problems overall. In contrast to these benchmarks, "government effectiveness" declines over the period under study, though the numbers for 2018 and 2019 are roughly similar. Data relating to QOL indicators are remarkably sparse for Ethiopia, and thus, there is little to say other than Ethiopia's infant mortality rate probability and secure internet server numbers improved over time.

The trend data do not support those worried the DSR in Ethiopia will have adverse political social-sustainability implications. Indeed, aside from the data for 2020, it hints that the DSR has positive results. This said, there is no factual evidence or logic establishing a link between the positive or negative political data found in our study of Ethiopia and the DSR to DSR projects, such as the aforementioned remote-sensing satellite, Huawei's mysterious smart city project, or Alibaba's e-WTP. Neither does our data indicate that the DSR is having significant positive social-sustainability ramifications with respect to QOL, though we are reluctant to push this point too far given the lack of good data.

Past, pessimistic analyses/forecasts about the DSR in Ethiopia have been off the mark for three reasons. First, they ignore the fact that the DSR in Ethiopia is not large in terms of numbers of projects or project value. Second, they give insufficient attention to the DSR's specific composition. While some DSR endeavors in Ethiopia (e.g., satellite cooperation) may be consequential, others like Alibaba's e-WTP, even if huge and wildly successful, are hardly likely to have any serious consequences for democracy, censorship, or traffic congestion. Third, they overstress the DSR while downplaying the relevance of the domestic (e.g., ethnic/tribal conflict which spurred a civil war) and international context, which may have the greatest ultimate effect on social sustainability in Ethiopia and the impact that the DSR eventually will have social sustainability in Ethiopia. 


\subsection{Malaysia}

\subsubsection{Malaysia-China Relations Overview}

Ties dramatically improved in the 1980s and 1990s and maintained an upward trend thereafter because of Malaysian political and economic needs and objectives. Political needs and objectives comprised, among other things, strengthening national independence, promoting peace in Southeast Asia (SEA), augmenting Malaysia's international voice, advancing favored regional and global agendas, and bolstering the standing of Malaysian leaders and political parties at home, particularly, on occasion, among the country's ethnic Chinese population. Economic needs and goals included delivering growth, diversifying economic partners, accelerating industrialization, expanding access to capital, and acquiring ICT. For its part, Beijing warmed ties with Malaysia initially because of the latter's role as a useful political partner in SEA and venues such as the Association of Southeast Asian Nations (ASEAN). Later, it came to see Malaysia as a meaningful trade and BRI partner, too [77] (pp. 97-100, 111-112).

Malaysia's trade with China jumped notably in the 1990s because of the two countries' growth, trade agreements, and the rise of SEA value added chains [77] (pp. 100-102). In 2000 , total merchandise trade ran $\$ 6.27$ billion. Ten years later, it jumped to $\$ 45.74$ billion. As of 2020, it totaled $\$ 78.58$ billion [60]. COFDI flows into Malaysia took off in the 2000s, but have been erratic. The AEI CGIT indicates they were $\$ 350$ million in 2010, soared to $\$ 6.54$ billion by the end of 2015, and dropped to $\$ 460$ million in 2020 [62]. Generally speaking, contracting and borrowing relations are much more impressive than FDI ties. In 2010, annual Malaysian contracts with Chinese companies were $\$ 1.81$ billion. Five years later, they were $\$ 1.26$ billion. Three years after this, they hit $\$ 2.85$ billion [62]. Malaysia has been one of the most "enthusiastic" participants in the BRI, signing agreements, participating in BRI Forums, lavishly praising China's scheme, welcoming BRI-related COFDI, and contracting numerous large-scale BRI projects. BRI projects include billion-dollar endeavors, such as the Gemas-Johor Baru double-tracking rail project, the Malaysia-China Kuantan Industrial Park/Kuantan Port, and the East Coast Rail Link [77-79].

\subsubsection{The DSR in Malaysia}

It is appropriate to treat Malaysia as a DSR country because there are many DSRtype projects in Malaysia. Furthermore, respected analysts opine Malaysia is a DSR participant [80]. Finally, Malaysian officials have expressed support for, praised, and touted the potential "crucial role" of Malaysia in the DSR [81-83]. The highest profile DSR project in Malaysia is the 2017 Digital Free Trade Zone (DFTZ), part of Alibaba's e-WTP. Among other things, Alibaba will provide design, hardware and software support (e.g., cloud computing), and services (e.g., logistics). Huawei's cooperation with entities in Malaysia on $5 \mathrm{G}$ and other telecommunications projects is also notable. Furthermore, Malaysia is working with China on an AI park and AI Innovation Center and potentially an ASEAN cloud computing hub. Two other DSR projects are a Kuala Lumpur (Malaysia's capital)Alibaba smart city project which emphasizes transportation management and diverse camera and surveillance system partnerships between Malaysia and Chinese firms [80]. Amounts and details for the aforementioned projects are lacking. Regardless, the potentially good and bad social-sustainability implications of these projects have not escaped notice, with some fretting about reduced freedom and privacy as a result of increased surveillance and others seeing less traffic congestion (a QOL improvement) [84-86].

\subsubsection{The DSR's Implications for Social Sustainability in Malaysia-Political Aspects}

The Freedom House FITW report labels Malaysia "partly free" every year from 2016 (the year before the DSR began in Malaysia) to 2020, the last year for which data are available. In 2016, Malaysia's scored 44 out of 100 in 2016 (due to problematic elections, the oppression of political opponents and movements, religious discrimination, and problems with the rule of law). The next year, it scored 45 out of 100 points (for many of the issues existing in 2016). In 2018, Malaysia's score improved to 52 out of 100 points because of 
some improvements in the rights of political opponents as well as minority groups (again not purely ethnically defined) and the rule of law. Malaysia's score remained the same in 2019. In 2020, it declined slightly to 51 out of 100 points due to signs of backtracking in various areas [87].

Turning to "freedom", our data source on surveillance reports the presence of 1000 cameras in Kuala Lumpur, which has a population of 1.8 million, and a relatively low geographic density of cameras [44]. As for privacy rights, our data sources did not yield the desired information for Malaysia. To measure censorship, we looked at the RSF WPFI and the Freedom House FOTN report. According to the RSF WPFI, Malaysia ranked 123 out of 179 in 2019, 101 out of 179 in 2020, and 119 out of 179 in 2021 [48]. The FOTN Report for 2016 gives Malaysia a score of 56 out of 100 for reasons such as content limits. For 2017, Malaysia garnered a score of 55 out of 100 for essentially the same reasons. The next year, the FOTN Report showed a score of 57 out of 100 because of some improvements on the content limits front. In 2019, Malaysia's score increased slightly to 58 because of, inter alia, fewer content limits [88]. For all of these years, the FOTN report labels Malaysia as "partly free".

The OECD Better Life Index does not provide information for Malaysia. We, therefore, drew upon Freedom House FITW report criteria B1, B3, and B4 scores to measure "participation" [87]. For 2016, it does not provide data for these criteria. In 2017, Malaysia scored 5 out of 12, partly because of limits on political organization and participation opportunities for minority groups. The next year, Malaysia's score was 6 out of 12 because of some improvements in the participation opportunities for minority groups. In 2019, the score for Malaysia remained the same. In 2020, there was no change in Malaysia's participation score.

World Bank "government effectiveness" data are available for Malaysia from 2016 to 2019. Malaysia's score is 0.87 in 2016, 0.83 in 2017, 1.08 in 2018, and 1 in 2019. It routinely scores far above the median for East Asia and the Pacific countries and better than all other SEA countries, and consistently ranks the second best after South Korea [51].

\subsubsection{The DSR's Implications for Social Sustainability in Malaysia-QOL Aspects}

The TomTom Traffic Index in 2017 gives Kuala Lumpur, the only Malaysian city for which data are compiled, a world rank of 43 out of 376 (a higher number is better) and a congestion level of 35 percent (a lower number is better). In 2018, Kuala Lumpur's rank was 44 out of 403 and its congestion level rose to 36 percent. In 2019, Kuala Lumpur realized a rank of 46 out of 416, with its congestion level increasing to 37 percent. In 2020, its rank declined to 77 out of 416, with the congestion level plummeting to 28 percent [89].

UNODC data do not provide any statistics about violent crimes (serious assault) or property crimes for Malaysia for the period under study. Looking at health issues, the infant mortality rate probability was 6.97 in 2016, 7.09 in 2017, 7.22 in 2018, and 7.32 in 2019 [54]. The WHO does not provide any data for "demand for family planning satisfied" for Malaysia for the years that we studied. It also does not provide any trend data for "road traffic crash deaths" for Malaysia and thus is not useful for our analysis.

Table 2 below presents information that portrays the situation with respect to "access to communications" in Malaysia. 
Table 2. Access to Communication Trends in Malaysia.

\begin{tabular}{lccccc}
\hline & $\mathbf{2 0 1 6}$ & $\mathbf{2 0 1 7}$ & $\mathbf{2 0 1 8}$ & $\mathbf{2 0 1 9}$ & $\mathbf{2 0 2 0}$ \\
\hline $\begin{array}{c}\text { Fixed Broadband } \\
\text { subscriptions (per 100) }\end{array}$ & 8.86 & 8.64 & 8.55 & 9.28 & Not available \\
\hline $\begin{array}{c}\text { Fixed Telephone } \\
\text { subscriptions (per 100) }\end{array}$ & 15.76 & 21.16 & 23.57 & 23.31 & Not available \\
\hline $\begin{array}{c}\text { Mobile cellular } \\
\text { subscriptions (per 100) }\end{array}$ & 141.65 & 136.12 & 134.53 & 139.56 & Not available \\
\hline $\begin{array}{c}\text { Secure internet servers } \\
\text { (per million) }\end{array}$ & 945.62 & 4917.79 & 5713.14 & 6723.93 & 7494.44 \\
\hline $\begin{array}{c}\text { Source: Authors's Compilation from World Bank [51] data. } \\
\quad\end{array}$ & & &
\end{tabular}

The numbers show improvements between 2016 and 2019 for every category, but mobile cellular subscriptions. There are notable changes in two metrics (fixed telephone subscriptions and secure internet servers). It is not clear if DSR-related access improvements, population changes, or other factors have driven the observed data patterns.

\subsubsection{Assessment}

For the period under study, the social-sustainability situation in Malaysia with respect to political metrics fluctuates, but is essentially static. The country's democracy score improves somewhat between 2016 and 2018, but remains largely the same from 2018 to 2020. Surveillance and censorship data do not reflect any notable improvements or decreases in "freedom". First, the data do not show a large number of surveillance cameras in the country whether evaluated in terms of aggregate numbers or geographic density. Second, RSF WPFI information shows what appears to be a significant improvement between 2019 and 2020, but the situation returns roughly to the 2019 level by 2021. Third, the Freedom House FOTN report data are roughly the same for 2016 to 2019. Looking at "participation", we see that, while there are fluctuations, Malaysia's score remains essentially the same for the period under study. In contrast, Malaysia's government effectiveness score for 2016 to 2019 is good and progresses to 1 in 2019 versus 0.87 in 2016. Shifting to QOL indicators, patterns are mixed. Malaysia's traffic congestion ranking improves from 2017 to 2020 with its congestion level continuously increasing before dropping dramatically in 2020. In addition, statistics with respect to infant mortality probabilities worsen from 2016 to 2019. Finally, access to communications data shows considerable variation.

In the aggregate, our data contradict the thesis that the DSR will produce negative political social-sustainability effects in Malaysia. There are, in fact, periods of time where the situation seems to improve, though it is incontrovertibly internal political dynamics inside Malaysia rather than DSR projects that are driving witnessed changes in democracy, censorship, and/or participation. The information presented in this case study suggests that the DSR in Malaysia is having some positive QOL social-sustainability implications with respect to traffic congestion and access to communications, but the data are not uniformly positive across all metrics. Moreover, in some cases, the positive data-e.g., plunging traffic congestion percentages-are not attributable to DSR projects, but other factors such as the COVID-19 pandemic.

The DSR in Malaysia has decent scale and scope, though a lack of public data makes it impossible to calculate the precise scale of certain projects or the degree to which specific projects have been implemented. Regardless, this case study calls into question the proclamations of optimists and pessimists alike. One potential explanation for the disconnect between their views and the reality on the ground is that the DSR is a relatively small part of Malaysia's overall infrastructure and ICT ecosystem. Another is that domestic (e.g., shifts in political coalitions and leaders) and international political dynamics probably play a far more critical role in determining the social-sustainability ramifications of DSR infrastructure and technology rather than the reverse. Another is that some components of the 
DSR, such as the AI Innovation Center or Alibaba's e-WTP, have very low probabilities of meaningfully affecting certain aspects of social sustainability, such as participation or QOL.

4.3. $U A E$

\subsubsection{UAE-China Relations Overview}

The UAE established diplomatic relations with China rather late. Starting in the 1990s, its links with China expanded primarily because of China's voracious energy appetite. Later, though, domestic and international political factors played an increasing role in lubricating closer ties between it and China. As for the former, engagement with China has advanced the UAE's economic development which, in turn, helps the regime deliver the economic goods that support its continued rule. As for the latter, closer dealings with China have expanded the UAE's choice of military cooperation partners, aided the UAE in hedging against the "folding" US security umbrella, and ameliorated, somewhat, regional ideological and military threats. Beijing has built up its relations with Abu Dhabi because of the latter's massive natural gas and oil endowments, relative stability, and its desire to bolster its position in the Arab/Muslim world and counter terrorist threats [90-92].

Trade between the UAE and China showed healthy growth throughout the 2000s and exploded in the 2010s [62] (p. 231). Total merchandise trade ran $\$ 2.11$ billion in 2000. By 2010 , it had reached $\$ 14.21$ billion. Nine years later, it had soared to $\$ 50.15$ billion [60]. With the exception of 2017 and 2018, COFDI flows into the UAE have not been very impressive over the past decade. In 2017, annual flows hit $\$ 2.96$ billion. The following year, they ran $\$ 2.23$ billion [62]. Generally speaking, contracting in terms of the number of deals and deal amounts has been far larger. In 2008, annual contracting totaled $\$ 3.55$ billion. Five years later, it was a measly $\$ 280$ million. However, in 2018, it reached $\$ 5.78$ billion [62]. The UAE has been a prominent and enthusiastic BRI participant from the get-go. It has participated in all key BRI events, promoted the BRI, signed numerous BRI MoUs, made the BRI a central part of its conversations with Chinese leaders, and established joint funding mechanisms with China to support the BRI and other projects. UAE-China completed or in-process BRI projects include industrial parks, logistics facilities, seaports, solar power complexes, and storage [90-92].

\subsubsection{The DSR in UAE}

The UAE signed a formal DSR MoU in 2017 [93]. Chinese firms having a strong DSR-related presence in the UAE include Alibaba and Huawei. Alibaba has a partnership with the Dubai Chamber of Commerce to launch an e-commerce platform and plans to build a $\$ 600$ million "Tech Town". It also cooperates with several UAE institutions on cloud computing and runs a data center with a local firm. Beyond this, it has established several fintech partnerships and is involved in smart-city projects in the UAE. For its part, Huawei is deeply involved in safe and smart city projects pertaining to Big Data, the management of urban lighting systems, and surveillance. It also has won large 5G contracts with UAE telecommunications firms, such as dU. Lastly, it operates a major customer service center in the UAE. Aside from these DSR projects, there are AI, data center, fintech, image recognition, and telecommunication projects involving Chinese companies such as China Mobile, China Telecom, and Megvii [12]. The aforementioned projects have given birth to debates about their social-sustainability ramifications relating to privacy, data leakage, and QOL (e.g., public service delivery) [94-96].

\subsubsection{The DSR's Implications for Social Sustainability in UAE-Political Aspects}

Delving into our democracy indicator, in 2016 (the year before the DSR began in the UAE), the FITW report gave the UAE a score of 20 out of 100 points due to a paucity of political rights, low transparency, and political repression. The next year, the UAE received a lower score of 17 out of 100 because of increased political repression. In 2018, 2019, and 2020, the UAE's scores were the same as in 2017. For all the years from 2016 to 2020, the FITW report designated the UAE "not free" [97]. 
Turning to "freedom", we were unable to obtain data on surveillance cameras per person or geographic density from our usual source. News and think tank reports indicate the UAE has deployed a huge number of cameras and may have one of the highest surveillance camera densities in the world [98]. We were unable to find any information about the UAE's privacy rights situation on the Privacy Rights International or the Electronic Privacy Information Center websites. To measure censorship, we used the RSF WPFI and the FOTN report. According to the RSF WPFI, the UAE ranked 133 out of 180 in 2019 due to very heavy surveillance and the persecution of journalists. The following year, it obtained a ranking of 131 out of 180. In 2021, the country's rank was 131 out of 180 [48]. The FOTN Report gives the UAE a score of 31 out of 100 for both 2016 and 2017 due to access limits, content restrictions, and other factors. In 2018, the UAE's score decreased to 28 out of 100 because of increased surveillance as well as content and usage restrictions. The next year, the country's FOTN Report score moved up slightly to 29 out of 100 [99]. For 2016 to 2019, the FOTN Report designates the UAE as "not free" [99].

The OECD Better Life Index does not provide any data for the UAE. In lieu of it, we make use of criteria B1, B3, and B4 scores from the FITW report to assess "participation". In 2016, the information in the FITW report did not allow us to measure participation. For 2017, the UAE earns a score of 2 out of 12 because of a lack of participation opportunities and constraints on minority political rights. In 2018, 2019, and 2020, the UAE's scores remaining the same as in 2017.

The UAE receives a 1.42 (out of 2.5) for government effectiveness in 2016, 1.42 in 2017, 1.43 in 2018, and 1.43 in 2019. Its scores are substantially higher than the median for the Middle East and North Africa, and indeed, it ranks higher than all Gulf Cooperation Council and even Israel [51].

\subsubsection{The DSR's Implications for Social Sustainability in UAE-QOL Aspects}

For 2017, the TomTom Traffic Index ranks Dubai ranked 116 out of 376 (higher is better) with a congestion level of 27 percent (lower is better). The next year, it improved to 202 out of 403 with a congestion level of 23 percent. In 2019, it increased to 265 out of 416 with a congestion level of 21 percent. In 2020, it declined to 230 out of 416 in 2020 with a congestion level of 19 percent [52]. In short, the traffic congestion trend seems to improve every year during the period under study except 2020.

UNODC data indicate that serious assaults declined from 348.0 per a population of 100,000 in 2016 to 223.0 in 2017 to 209.0 in 2018 [100]. For 2015, robberies fell from 378.0 per a population of 100,000 in 2016 to 297.0 in 2017. There are no data for any of the other years that we study [101]. As for property related crime, burglaries fell from 942 per a population of 100,000 in 2016 to 872 in 2017 to 863 in 2018 [102]. Turning to WHO data, we find that infant-mortality-rate probabilities decreased from 6.64 in 2016 to 6.58 in 2017 to 6.51 in 2018 [54]. As for the demand for family planning and road-traffic deaths, the WHO Observatory does not provide data for the UAE for the years relevant to this analysis.

In Table 3 below, we provide data that illuminate the situation regarding access to communications in the UAE.

The data show improvements in fixed broadband subscriptions and secure internet servers (though the number in 2020 versus 2019 is lower). Fixed telephone subscriptions are roughly stable, and mobile cellular subscriptions decline from 2016 to 2019. However, it is not clear if the drop is a significant one. 
Table 3. Access to Communications in the UAE.

\begin{tabular}{cccccc}
\hline & $\mathbf{2 0 1 6}$ & $\mathbf{2 0 1 7}$ & $\mathbf{2 0 1 8}$ & $\mathbf{2 0 1 9}$ & $\mathbf{2 0 2 0}$ \\
\hline $\begin{array}{c}\text { Fixed Broadband } \\
\text { subscriptions (per 100) }\end{array}$ & 13.862 & 29.111 & 31.405 & 31.175 & Not available \\
\hline $\begin{array}{c}\text { Fixed Telephone } \\
\text { subscriptions (per 100) }\end{array}$ & 24.418 & 24.463 & 24.311 & 24.181 & Not available \\
\hline $\begin{array}{c}\text { Mobile cellular } \\
\text { subscriptions (per 100) }\end{array}$ & 212.6349 & 208.797 & 208.505 & 200.632 & Not available \\
\hline $\begin{array}{c}\text { Secure internet servers } \\
\text { (per million) }\end{array}$ & 938.684 & 1285.99 & 1483.963 & 1912.077 & 1405.504 \\
\hline $\begin{array}{c}\text { Source: Authors' Compilation from World Bank [76] Data. } \\
\text { Auth }\end{array}$
\end{tabular}

Source: Authors' Compilation from World Bank [76] Data.

\subsubsection{Assessment}

The UAE's democracy scores are essentially the same from 2016 to 2020, with Freedom House labeling it "not free" for all these years. As for freedom, we do not have any trend data about surveillance patterns, but the country is heavily populated with surveillance cameras. Our two sources of information for gauging censorship indicate the UAE's scores are largely the same over the period that we analyzed. This stability in scores, with some minor increases/decreases from year to year, also is witnessed with respect to the data relating to "participation" and "government effectiveness". As for social-sustainability metrics pertaining to QOL, the news seems to be positive on the traffic congestion front, safety (with declines witnessed in serious and property crimes across the period that we reviewed), and infant mortality probabilities. Data on "access to communication" are somewhat mixed. This being said, the trend for three of our four "access to communication" metrics is positive or stable.

DSR infrastructure is notable in the UAE. However, it has little or no implications for the political aspects of social sustainability, which is intriguing given most reflecting about the DSR and UAE social sustainability are concerned about its potential to worsen the political situation. In contrast, there is a positive correlation between the DSR and QOL aspects of social sustainability. In our view, the disconnect between the DSR and the political aspects of social sustainability has to do with the fact that larger political forces determine the political environment in the country. The apparent success of the DSR in enhancing QOL may have to do with the nature of the DSR in the UAE. Specifically, safe and smart cities and telecommunications projects logically connect to improvements in traffic congestion, reductions in certain types of crime, and better communications access.

\subsection{Hungary}

\subsubsection{Hungary-China Relations Overview}

Hungary established diplomatic relations with the PRC in October 1949, making it among the first countries to do so. Ties experienced tensions in the 1960s and 1970s because of Sino-Soviet frictions, but improved somewhat in the late 1970s and 1980s because China saw Hungary as a model of economic reform $[103,104]$. The relationship really started to grow after Hungary became a member of the European Union (EU) in 2004 [103,105]. It was the 2008 Great Financial Crisis, however, that really spurred Hungary to move closer to China as a way of reducing its dependence on Western markets and capital and realizing Prime Minister Viktor Orbán's goal of attracting more COFDI [105,106]. Indeed, Orban's Hungary has been one of the most China-friendly countries in the EU in recent years [107]. This is well illustrated by various events. In January 2021, Hungary became the first EU member to approve China's Sinopharm COVID vaccine. Two months later, it slammed EU sanctions against China, the first it had imposed in over 30 years $[108,109]$. Hungary's disposition towards China also is reflected by the fact it was the only Visegrad country that sent representatives at the highest level to all the post-2012 summits under the $16 / 17+1$ cooperation framework between Central and Eastern European Countries (CEEC) and 
China [110]. For China, good relations with Hungary have yielded political support (as just described) and provided access to the European market and an attractively located, low-cost manufacturing environment [111].

When it comes to their economic relations, the total trade volume in goods between China and Hungary increased from almost $\$ 1$ billion to $\$ 7.7$ billion in 2010 to over $\$ 10$ billion in 2020 [60]. Of note, Hungary's imports from China dwarf its exports to the country [105]. Annual COFDI flows to Hungary are rather trivial. They hit $\$ 1.92$ billion in 2011, \$210 million in 2017, and \$110 million in 2019 [62]. EU FDI into Hungary dwarfs COFDI, with total EU FDI accounting for close to 70 percent of Hungary's stock [112]. Per CGIT, the value of Chinese construction in Hungary was around \$1 billion in both 2019 and 2020 due to contracts won by China Railway Engineering [62].

In 2015, Hungary was the first EU member state to join the BRI. It did so partly for economic reasons, but political rationales were salient, too, with Hungary seeing the BRI as a pathway to asserting independence from an alleged EU "dictatorship" [113,114]. In terms of concrete BRI cooperation, Hungary and China signed a loan agreement in April 2020 to finance the construction of a $370 \mathrm{~km}$ Budapest-Belgrade railway link, with Hungary providing 15 percent of the financing and China financing the balance with a loan [115]. The railway project has experienced repeated delays since the MoU for the railway was signed in December 2014 [115]. Another project is a massive Fudan University campus in Budapest, reportedly valued around $\$ 1.8$ billion, with Hungary taking out a $\$ 1.5$ billion Chinese loan and using Chinese contractors to complete the project [116,117].

\subsubsection{The DSR in Hungary}

In April 2019 at the 2nd BRIF, the Hungarian delegation signed various agreements, including one pertaining to the DSR, with their Chinese counterparts. On the sidelines of the same BRIF, Huawei signed an agreement with the University of Szeged on R\&D in information technologies while ZTE ITS, a ZTE subsidiary engaged in smart transportation, signed deals with Hungary's GB \& Partners and EPS Global on car parking management. There are various other initiatives in the digital space, with Huawei especially prominent. In July 2019, Hungary signed an MoU strengthening Huawei's role in developing the country's ICT sector, outlining concrete measures the parties will take under an earlier agreement. In partnership with Huawei, Vodafone Hungary was the first operator that launched commercial 5G services in October 2019. In May 2021, Huawei launched an innovative AirPON optical access solution to help Hungary meet its goal of providing high-speed network connections. In May 2019, operator Telenor launched pilot telecommunications services in Győr (Northwest Hungary) using technology from ZTE. Turning to the field of surveillance technology, in mid-2021, Dahua Technology won a tender to install 39 new surveillance cameras equipped with artificial intelligence in the popular Hungarian holiday destination Siofok. Unfortunately, scant information on these projects makes it challenging to paint a detailed portrait of them. In any event, some fret that DSR infrastructure in Hungary might have negative ramifications for social-sustainability facets, such as democracy and government effectiveness, because of potential negative effects on government transparency and corruption. There also are concerns about the democracy and privacy implications of Dahua's face recognition cameras given the firm's role in Xinjiang and prior data-protection scandals [118].

\subsubsection{The DSR's Implications for Social Sustainability in Hungary-Political Aspects}

To gauge Hungary's democratic situation, we use FITW reports. The 2019 report on the situation in 2018 states that the country's status declined from "Free" to "Partly Free" because of Orbán's Fidesz party's sustained attacks on Hungary's democratic institutions. Its score was 70 out of 100 and remained the same in 2019. In the most recent 2021 FITW report, Hungary earned a 69 out of 100 score for 2020, with the report highlighting that the Fidesz-led government has "moved to institute policies that hamper the operations of op- 
position groups, journalists, universities, and NGOs who criticize it or whose perspectives it otherwise finds unfavorable" [119].

Turning to "freedom", we first focus on surveillance. Per Comparitech data, in 2019, with 3.40 CCTV cameras per 1000 people, Budapest ranked sixth in the EU. The Hungarian government has "invested significantly in pre-investigation surveillance of the population" and recently authorized $\$ 131.3$ million to enhance such a surveillance system [120]. We did not find any systematic studies of privacy trends in Hungary. As for censorship, per the FOTN report, Hungary scored 71 out of 100 in 2018, 72 out of 100 in 2019, and 71 out of 100 in 2020 [121]. In all three reports, the FOTN report deemed Hungary "free". As for the WPFI, Hungary ranked 73th out of 180 in 2018, 87th out of 180 in 2019, 89th out of 180 in 2020, and 92th out of 180 in 2021. The 2018 merger of over 400 media into one nonprofit conglomerate loyal to the government put an end to media pluralism in Hungary [122]. This was part of a broader trend of political interference in the media. According to HRW, the firing of the editor-in-chief of Hungary's biggest independent news website in July 2020, "had political interference written all over it" [123].

The OECD Better Life Index defines participation as civic engagement or "your involvement in democracy". In 2020, Hungary earned a score of 3.4, with 10 being the maximum [124]. However, the Index did not provide any information allowing us to assess participation trends. Thus, we turned to participation-related measures (B1, B3, and B4) in the FITW report. The 2018 report, predominantly focusing on the key developments in 2017, gave Hungary a score of 9 out of 12. There were no changes in Hungary's scores in the three subsequent report covering 2018, 2019, and 2020.

To assess "good governance", we used government effectiveness info provided by the World Bank (see below). The data reveal that the score remained roughly similar for the period of our research, with a 0.52 score in 2017, 0.49 in 2018, and 0.50 in 2019 [51]. The highest score possible is 2.5 while the lowest score possible is -2.5 .

\subsubsection{The DSR's Implications for Social Sustainability in Hungary-QOL Aspects}

Concerning "transportation", Hungary has one city, its capital Budapest, in the TomTom Traffic Index. The Index started in 2017, and the Hungarian capital has seen an increase in congestion levels since then [125]. Budapest's congestion level was 31 percent in 2017, 35 percent in 2018, 37 percent in 2019, and 27 percent in 2020. The 10 percentage point decrease in congestion between 2019 and 2020 was predominantly due to reduced traffic resulting from the COVID-19 pandemic.

Our aim was to obtain information on "safety" by drawing upon UNODC data, paying special attention to data on violent and property crimes [53]. However, UNODC data on serious assault, robbery, kidnapping, burglary, and (car) theft are only available until 2018. Thus, it is not possible to evaluate any patterns that might flow from the implementation of the DSR.

As for "health", we considered data on child mortality, family planning access, and road traffic deaths compiled by the WHO Global Health Observatory. In 2017, the infant mortality rate (probability of dying between birth and age 1 per 1000 live births) was 3.62; it was 3.31 in 2018 and 3.03 in 2019 [54]. There were no data for Hungary relating to demand for family planning satisfied. Hungary's estimated road traffic death rate (per 100.000 population) remained largely unchanged, with scores of 7.75 in 2016, 7.99 in 2017, 8.12 in 2018, and 7.74 in 2019 [56]. One can question if the road safety patterns have any DSR connection since the European Road Safety Observatory notes that traffic safety in Hungary has much to do with the fact that Hungarian vehicles are much older than the EU average and that seat-belt-wearing rates in Hungary are below the EU average [126].

Table 4 below presents information portraying the situation in Hungary regarding access to communications. 
Table 4. Access to Communications in Hungary.

\begin{tabular}{ccccc}
\hline & $\mathbf{2 0 1 7}$ & $\mathbf{2 0 1 8}$ & $\mathbf{2 0 1 9}$ & $\mathbf{2 0 2 0}$ \\
\hline $\begin{array}{c}\text { Fixed Broadband } \\
\text { subscriptions (per 100) }\end{array}$ & 30.387 & 31.723 & 32.935 & Not available \\
\hline $\begin{array}{c}\text { Fixed Telephone } \\
\text { subscriptions (per 100) }\end{array}$ & 32.186 & 31.725 & 31.48 & Not available \\
\hline $\begin{array}{c}\text { Mobile cellular } \\
\text { subscriptions (per 100) }\end{array}$ & 102.212 & 103.445 & 106.072 & Not available \\
\hline $\begin{array}{c}\text { Secure internet servers } \\
\text { (per million) }\end{array}$ & 13.627 & 19.244 & 26.241 & 32.814 \\
\hline Source: Authors' Compilation from World Bank [76] Data. & &
\end{tabular}

Source: Authors' Compilation from World Bank [76] Data.

The table reveals improvement in all categories except for fixed telephone subscriptions per 100. Secure internet servers showed the most dramatic improvement.

\subsubsection{Assessment}

Democracy indicators show a negative trend for the period under study, though no major changes year to year. As for freedom, we did not locate any surveillance trend data; however, as we noted, the government is investing significantly in surveillance. We could not locate systematic data on privacy trends, but censorship data showed mixed trends, with the WPFI indicating steady decline while FOTN showing little change. According to the FITW report, participation trends were essentially static for all the years under consideration. Data on government effectiveness revealed that the score remained roughly similar, albeit low, during the period we studied. Concerning QOL, TomTom Traffic Index and UNODC data limitations do not allow us to assess traffic congestion or safety trends. Regarding health, we see moderate, slow improvements in child mortality rate probabilities, the only metric for which we garnered sufficient data. As for "access to communications", the benchmarks collectively show a trend of improvement [76].

In the Hungary case, various facts stand out. One is that, despite some of the aforementioned anxieties, there are no notable changes or clear up or down trends in some political social-sustainability indicators. A second is that witnessed changes may be driven more by domestic political dynamics than the DSR. In fact, for many, Hungary is a paradigmatic example of a European country characterized by democratic backsliding and a troubled relationship with the EU $[127,128]$. Moreover, the decline in the political indicators for Hungary already began before the start of the DSR. As for QOL, there are no dramatic positive or negative changes or clear up or down trends. It also is debatable if changes or trends have anything to do with the DSR. Unfortunately, a lack of public data makes it impossible to present a detailed portrait of many DSR projects. If the DSR, in actuality, was much smaller than believed, this might explain the disconnect between it and Hungary's social-sustainability trends. In contrast, if the DSR, in actuality, was much larger than believed, this would only add credence to the thesis that the DSR is only a small part of the social-sustainability story unfolding in Hungary.

\section{Discussion and Conclusions}

Infrastructure investment is a critical development issue, an integrated part of contemporary geopolitics, and one of the core features of China's BRI. However, as the Special Issue call for papers correctly observes, there is insufficient understanding about how infrastructure will affect society, the economy, and QOL. We engage the debate by examining the social-sustainability implications of infrastructure through the lenses of DSR infrastructure, which has garnered both positive and negative assessments-some quite strong-about its ramifications for social sustainability. As we noted, however, the extant literature has some serious methodological and empirical issues. In this article, we directly tackled these shortcomings after providing a primer on the DSR. We first advanced a novel scheme for operationalizing social sustainability. We then used our original framework to 
systematically assess the social-sustainability impacts of DSR infrastructure in four country cases in Africa, Southeast Asia, the Middle East, and Europe. We further contemplated the extent to which DSR infrastructure was associated with observed changes.

Our study adds value in various ways. For example, it demonstrates that the extant DSR literature is problematic. Despite the arguments of the optimists and pessimists, none of our cases shows any dramatic positive or negative changes in political or QOL sustainability metrics. It also reveals that the sustainability effects of DSR infrastructure depend upon its scale, scope, and nature. Furthermore, it shows that context matters. For example, positive political social-sustainability trends in Ethiopia and negative political social-sustainability trends in Hungary are more attributable to domestic political factors. Together, all of this suggests that infrastructure should be viewed as a tool without predetermined positive or negative social-sustainability effects that ultimately are determined by factors we have mentioned and likely by the way governments, businesses, and others use it. Our research calls into question, too, the presumption that the DSR is as large in scale and scope as some presume. Finally, our comparative case analysis of countries located in different regions of the world, featuring different DSR components, and possessing different levels of socioeconomic development and regional organization memberships, expands the database on the effects of DSR infrastructure specifically and infrastructure more generally.

The academic value of our article is threefold. First, we contribute to knowledge about the socioeconomic effects of infrastructure. Second, we advance a novel scheme for operationalizing social sustainability, which facilitates systematic, as well as comparative case, analysis. Third, our work is a corrective to some misplaced assessments of the DSR's impact. For policymakers and businesspeople, our work indicates that there should be less anxiety about the DSR and its effects. In addition, it shows that it is essential to consider the context when evaluating the impact of Chinese infrastructure initiatives like the DSR. Lastly, for China and Chinese companies, it suggests that adjustments must be made to the scale and scope of the DSR if the former and/or latter wish to maximize the social-sustainability gains that it delivers. In other words, China and DSR participants need to ensure that DSR infrastructure, laws, regulations, policy, and so on are "done right" (e.g., in terms of DSR project features or taking into account the political-economic context) if they wish to generate positive DSR externalities while minimizing its negative ones.

Despite our article's important contributions, it has some limitations. One is that it has proven that it is difficult to obtain detailed data on DSR infrastructure, especially due to the pandemic. We plan to rectify this via future fieldwork. A second is that not all of our benchmarks proved to be as useful as originally envisioned. In future work, we hope to locate some better metrics that meet our enumerated standards. A third issue is that we need to unpack our measures further to eliminate potential multicollinearity issues. At this point, though, it is more critical to develop and apply a sensible and well-structured operationalization scheme that moves the debate forward rather than to get mired in a vain quest for perfection. Fourth, in future studies, we must consider how to aggregate the metrics used to measure our variables. Finally, the DSR is an evolving initiative, and what is true today may not be true in the future. Thus, ongoing research is required, especially since the political, legal, and regulatory environment for technology companies in China and the rules governing Chinese companies, their products, and their services abroad are constantly evolving. On a related note, as social-sustainability operationalization schemes are perfected and the universe of data expands, it may be fruitful to use quantitative analysis to study the social-sustainability effects of the DSR.

Infrastructure is seen as a panacea for many developmental ills. In the pandemic era, many countries see technology infrastructure, as embodied in China's DSR, among other schemes, as an attractive way to boost their growth, diversify their economies, improve their QOL, engage more with the global economy, and move up the value-added chain. Some warn of serious adverse social-sustainability effects, while others tout the benefits of China's initiative. As one of us has shown elsewhere and this study shows, 
connectivity is complicated, and the links that flow from it cannot be assumed but must be carefully uncovered with a proper analytical framework, as we ourselves have endeavored to do here.

Author Contributions: This article represents the joint work of both authors. J.-M.F.B. conceptualized the article, developed the social sustainability operationalization scheme and methodology, prepared the Ethiopia, Malaysia, and UAE case studies, and took the lead in generating the first article draft. B.H. prepared the Hungary case study, helped refine the article's operationalization scheme and methodology as well as the aforementioned three case studies, and aided in the finalization of the article. Both authors played a role in data gathering and analysis. All authors have read and agreed to the published version of the manuscript.

Funding: This research received no external funding.

Institutional Review Board Statement: Not applicable.

Informed Consent Statement: Not applicable.

Data Availability Statement: Not applicable.

Conflicts of Interest: The authors declare no conflict of interest.

\section{References}

1. Kant, R. Digital Silk Road: Xi's Dream of Conquering Asia. Asia Times. Available online: https://asiatimes.com/2019/06/ digital-silk-road-xis-dream-of-conquering-asia (accessed on 26 June 2019).

2. Kurlantzick, J. China's Digital Silk Road Initiative: A Boon for Developing Countries or a Danger to Freedom? The Diplomat. Available online: https:/ thediplomat.com/2020/12/chinas-digital-silk-road-initiative-a-boon-for-developing-countries-ora-danger-to-freedom (accessed on 17 December 2020).

3. Kynge, J.; Hopkins, V.; Warrell, H.; Hille, K. Exporting Chinese Surveillance: The Security Risks of 'Smart Cities. Financial Times. Available online: https:/ / www.ft.com/content/76fdac7c-7076-47a4-bcb0-7e75af0aadab (accessed on 8 June 2021).

4. People's Republic of China, State Council. Digital Silk Road on Path to Sustainable Development: Expert. Available online: http:/ / english.www.gov.cn/news/top_news/2017/09/05/content_281475837559524.htm (accessed on 5 September 2017).

5. Ren, X. Digital Silk Road Helping Developing Countries. China Daily. Available online: https://www.chinadaily.com.cn/a/2019 04/27/WS5cc3a6e7a3104842260b8add.html (accessed on 27 April 2019).

6. Xie, L. Belt and Road Initiative a public road for public good: China Daily. The Straits Times. Available online: https: //www.straitstimes.com/asia/bri-a-public-road-for-public-good-china-daily-contributor (accessed on 21 April 2021).

7. Zou, R. China's Digital Silk Road: A Pathway to Post-Pandemic Economic Recovery? China Focus. Available online: https:/ / www.chinausfocus.com/finance-economy/chinas-digital-silk-road-a-pathway-to-post-pandemic-economic-recovery (accessed on 19 August 2020).

8. Blanchard, J.-M.F. Belt and Road Initiative (BRI) Blues: Powering BRI Research Back on Track to Avoid Choppy Seas. J. Chin. Political Sci. 2021, 26, 235-255. [CrossRef]

9. Creemers, R. (Ed.) The Digital Silk Road: Perspectives from Affected Countries; Leiden Asia Centre: Leiden, The Netherlands, 2021. Available online: https:/ / leidenasiacentre.nl/wp-content/uploads/2021/08/Digital-Silk-Road-Perspectives-From-AffectedCountries.pdf (accessed on 25 July 2021).

10. OECD. OECD Digital Economy Outlook 2020. Available online: https://www.oecd-ilibrary.org/sites/bb167041-en/index.html? itemId=/content/publication/bb167041-en (accessed on 2 August 2021).

11. Ghiasy, R.; Krishnamurthy, R. China's Digital Silk Road: Strategic Implications for the EU and India; Special Report \#208; LAC and IPCS: New Delhi, India, 2020.

12. Blanchard, J.-M.F.; Hooijmaaijers, B. Disconnecting European Companies and Countries? Case Studies call for Modulating Worries about China's Digital Silk Road. Eur. J. Int. Manag. Accepted.

13. Lilkov, D. Made in China: Tackling Digital Authoritarianism; Wilfried Martens Centre for European Studies: Brussels, Belgium, 2020.

14. Ly, B. Challenge and perspective for Digital Silk Road. Cogent Bus. Manag. 2020, 7, 1804180. [CrossRef]

15. Prasso, S. China's Digital Silk Road Is Looking More Like an Iron Curtain. Bloomberg BusinessWeek. Available online: https: / / www.bloomberg.com/news / features/2019-01-10/china-s-digital-silk-road-is-looking-more-like-an-iron-curtain (accessed on 9 January 2019).

16. Mochinaga, D. The Digital Silk Road and China's Technological Influence in Southeast Asia; CFR Blog. Available online: https:/ / www.cfr.org/blog/digital-silk-road-and-chinas-technology-influence-southeast-asia (accessed on 16 June 2021).

17. Shen, H. Building a Digital Silk Road? Situating the Internet in China's Belt and Road Initiative. Int. J. Commun. 2018, 12, 2683-2701.

18. Cheney, C. China's Digital Silk Road: Strategic Technological Competition and Exporting Political Illiberalism; Pacific Forum Issues \& Insights Working Paper; Pacific Islands Forum: Suva, Fiji, 2019; Volume 19, p. WP8. 
19. Hemmings, J. Reconstructing Order. Asia Policy 2020, 15, 5-21. [CrossRef]

20. Greene, R.; Triolo, P. Will China Control the Global Internet Via its Digital Silk Road? Carnegie Endowment for International Peace: Washington, DC, USA, 2020.

21. Dekker, B.; Okano-Heijmans, M.; Zhang, E.S. Unpacking China's Digital Silk Road; Clingendael: Den Haag, The Netherlands, 2020.

22. Hodson, H. With the State's Help, Chinese Technology is Booming. The Economist. Available online: https://www.economist. com/technology-quarterly/2020/01/02/with-the-states-help-chinese-technology-is-booming (accessed on 2 January 2020).

23. Olander, E.C. China and the Rise of AI-Surveillance Technology in Africa. The China Africa Project. Available online: https: / / chinaafricaproject.com/analysis / china-and-the-rise-of-ai-surveillance-technology-in-africa (accessed on 19 September 2019).

24. Garcia, A. China Embarks on Digital Silk Road. AP Institutional Invesco. Available online: https://www.invesco.com/apac/en/ institutional/insights/china/china-embarks-on-digital-silk-road.html (accessed on 27 May 2019).

25. Warraell, H.; Fildes, N. UK Spies Warn Local Authorities over 'Smart City' Tech Risks. Financial Times. Available online: https: / / www.ft.com/content/46d35d62-0307-41d8-96a8-de9b52bf0ec3 (accessed on 6 May 2021).

26. Rogers, P.P.; Jalal, K.F.; Boyd, J.A. An Introduction to Sustainable Development; Earthscan: London, UK, 2008.

27. Fricker, A. Measuring Up to Sustainability. Futures 1998, 30, 367-375. [CrossRef]

28. Ramsey, J.L. On Not Defining Sustainability. J. Agric. Environ. Ethics 2015, 28, 1075-1087. [CrossRef]

29. Bell, S.; Morse, S. Sustainability Indicators: Measuring the Immeasurable? 2nd ed.; Earthscan: London, UK, 2008.

30. Surampalli, R.Y.; Zhang, T.C.; Goyal, M.K.; Brar, S.K.; Tyagi, R.D. (Eds.) Sustainability: Fundamentals and Applications; John Wiley: Hoboken, NJ, USA, 2020.

31. Wilkinson, A.; Hill, M. The Sustainability Debate. Int. J. Oper. Prod. Manag. 2001, 21, 1492-1502. [CrossRef]

32. Portney, K.E. Sustainability; The MIT Press: Cambridge, MA, USA, 2015.

33. Scoones, I. Sustainability. Dev. Pract. 2007, 17, 589-596. [CrossRef]

34. Thompson, P.B.; Norris, P.E. Sustainability: What Everyone Needs to Know; Oxford University Press: New York, NY, USA, 2021.

35. Wheelen, T.L.; Hunger, D.J.; Hoffman, A.N.H.; Bamford, C.E. Strategy Management and Business Policy: Globalization, Innovation, and Sustainability; Pearson: Harlow, UK, 2018.

36. Costanza, R.; Patten, B.C. Defining and Predicting Sustainability. Ecol. Econ. 1995, 15, 193-196. [CrossRef]

37. Talan, A.; Tyagi, R.D.; Surampalli, R.Y. Social Dimensions of Sustainability. In Sustainability: Fundamentals and Applications; Surampalli, R.Y., Zhang, T.C., Goyal, M.K., Brar, S.K., Tyagi, R.D., Eds.; John Wiley: Hoboken, NJ, USA, 2020 ; pp. $183-206$.

38. Eizenberg, E.; Jabareen, Y. Social Sustainability: A New Conceptual Framework. Sustainability 2017, 9, 68. [CrossRef]

39. Ajmal, M.M.; Khan, M.; Hussain, M.; Helo, P. Conceptualizing and incorporating social sustainability in the business world. Int. J. Sustain. Dev. World Ecol. 2018, 25, 327-339. [CrossRef]

40. Lucato, W.C.; da Silva Santos, J.C.; Tadeu Pacchini, A.P. Measuring the Sustainability of a Manufacturing Process: A Conceptual Framework. Sustainability 2017, 10, 81. [CrossRef]

41. Sudusinghe, J.I.; Seuring, S. Social Sustainability Empowering the Economic Sustainability in the Global Apparel Supply Chain. Sustainability 2020, 12, 2595. [CrossRef]

42. Talan, A.; Pathak, A.N.; Tyagi, R.D. The Need, Role, and Significance of Sustainability. In Sustainability: Fundamentals and Applications; Surampalli, R.Y., Zhang, T.C., Goyal, M.K., Brar, S.K., Tyagi, R.D., Eds.; John Wiley: Hoboken, NJ, USA, 2020; pp. 21-41.

43. Freedom House. Freedom in the World. Available online: https://freedomhouse.org/report/freedom-world (accessed on 18 July 2021).

44. Visual Capitalist. Mapped: The Top Surveillance Cities Worldwide. Available online: https://www.visualcapitalist.com/ mapped-the-top-surveillance-cities-worldwide/ (accessed on 1 January 2021).

45. Privacy International. Privacy International. Available online: https:/ / privacyinternational.org (accessed on 12 July 2021).

46. Electronic Privacy Information Center. Electronic Privacy Information Center. Available online: http:/ / www.epic.org (accessed on 24 July 2021).

47. Freedom House. Freedom on the Net. Available online: https:// freedomhouse.org/report/freedom-net (accessed on 12 July 2021).

48. Reporters without Borders. World Press Freedom Index. Available online: https://rsf.org/en/ranking (accessed on 12 July 2021$)$.

49. Human Rights Watch. Countries. 2021. Available online: https://www.hrw.org/countries (accessed on 23 July 2021).

50. OECD Better Life Index. Civic Engagement. Available online: https://www.oecdbetterlifeindex.org/topics/civic-engagement (accessed on 15 August 2021).

51. World Bank. GovDate360, Government Effectiveness. Available online: https://govdata360.worldbank.org/indicators/h580f9 aa5 (accessed on 8 August 2021).

52. TomTom. TomTom Traffic Index. Available online: https://www.tomtom.com/en_gb/traffic-index/ (accessed on 15 July 2021).

53. United Nations Office on Drugs and Crime. dataUNODC. Available online: https://dataunodc.un.org/data (accessed on 25 July 2021).

54. World Health Organization. The Global Health Observatory. Infant Mortality Rate (Probability of Dying between Birth and Age 1 per 1000 Live Births. Available online: https:/ / www.who.int/data/gho/data/indicators/indicator-details/GHO/infantmortality-rate-(probability-of-dying-between-birth-and-age-1-per-1000-live-births) (accessed on 14 August 2021). 
55. World Health Organization. The Global Health Observatory. Health Equity Monitor: Demand for Family Planning Satisfied-Use of Modern and Traditional Methods (\%). Available online: https://www.who.int/data/gho/data/indicators/indicator-details/ GHO/demand-for-family-planning-satisfied---modern-and-traditional-methods-(-) (accessed on 14 August 2021).

56. World Health Organization. The Global Health Observatory, Estimated Road Traffic Death Rate (per 100,000 Population). Available online: https://www.who.int/data/gho/data/indicators/indicator-details/GHO/estimated-road-traffic-death-rate(per-100-000-population) (accessed on 14 August 2021).

57. World Bank. Infrastructure. Available online: https://data.worldbank.org/topic/infrastructure (accessed on 8 August 2021).

58. Blanchard, J.-M.F.; Ziso, E. The Maritime Silk Road Initiative and Ethiopia: Transforming Policies, Institutions, and Politics in Expected and Unexpected Ways. In China's Maritime Silk Road Initiative, Africa, and the Middle East: Feats, Freezes, and Failure; Blanchard, J.-M.F., Ed.; Palgrave Macmillan: Singapore, 2021; pp. 81-110.

59. Shinn, D.H. Ethiopia and China: Two Former Empires Connect in the 20th Century. Int. J. Ethiop. Stud. 2014, 8, 149-164.

60. United Nations. UN Comtrade. Available online: https:/ / comtrade.un.org/data (accessed on 21 July 2021).

61. Nicolas, F. Chinese Investors in Ethiopia: The Perfect Match? Notes de Ifri: Paris, France, 2017.

62. American Enterprise Institute. China Global Investment Tracker. Available online: https://www.aei.org/china-globalinvestment-tracker (accessed on 2 August 2021).

63. Wheatley, J.; Cotterill, J.; Munshi, N. African Debt to China: A Major Drain on the Poorest Countries. Financial Times. Available online: https://www.ft.com/content/bd73a115-1988-43aa-8b2b-40a449da1235 (accessed on 25 October 2020).

64. Blanchard, J.-M.F. Problematic Prognostications about China's Maritime Silk Road Initiative (MSRI): Lessons from Africa and the Middle East. J. Contemp. China 2020, 29, 159-174. [CrossRef]

65. China.org. Interview: BRI to Further Boost Comprehensive Ethiopia-China Ties: Official. Available online: www.china.org.cn/ world/Off_the_Wire/2019-04/22/content_74709665.htm (accessed on 22 April 2019).

66. Ethiopia, China Sign USD 1.8bln Investment Agreement. Available online: https:/ / ethiopianembassy.org/ethiopia-china-signusd-1-8bln-investment-agreement-april-24-2019 (accessed on 14 April 2019).

67. Tan, J. Solidarity, Cooperation: The Only Way Tackling COVID-19 Crisis. Ethiopian News Agency. Available online: https: / / www.ena.et/en/?p=15501 (accessed on 17 June 2020).

68. China.org. Inspur Launches the 'B\&R' Digital Economy Strategic Alliance. Available online: www.china.org.cn/business/2017-1 1/03/content_41844832.htm (accessed on 3 November 2017).

69. Gitau, M. Ethiopia's Satellite Plans Come with Strings Attached. Africa Times. Available online: https://africatimes.com/2018/1 2/06/ethiopias-satellite-plans-come-with-strings-attached (accessed on 6 December 2018).

70. Meester, J. Designed in Ethiopia and 'Made in China' Sino-Ethiopian Technology Collaboration in South-South Relations; Clingendael Institute CRU Policy Brief the Hague: Den Haag, The Netherlands, 2021.

71. Van der Lugt, S. Exploring the Political, Economic, and Social Implications of the Digital Silk Road into East Africa. In Global Perspectives on China's Belt and Road Initiative: Asserting Agency through Regional Connectivity; Schneider, F., Ed.; Amsterdam University Press: Amsterdam, The Netherlands, 2021; Volume 315-346.

72. Dahir, A.L. Ethiopia Is Set to Launch Its First Satellite into Space-With China's Help. Quartz Africa. Available online: https:/ / qz.com/africa/1474369/china-to-help-launch-ethiopias-first-satellite-in-2019 (accessed on 26 November 2018).

73. Global Times. Ethiopia Seeks Enhanced Space Science Cooperation with China. Available online: https://www.globaltimes.cn/ content/1176748.shtml (accessed on 14 January 2020).

74. Hillman, J.E.; McCalpin, M. Watching Huawei's Safe Cities; CSIS Brief: Washington, DC, USA, 2019.

75. Addis Standard. News: Alibaba Group to Help Ethiopia Set Up First eWTP Hub, the Second in Africa. Available online: https: / / addisstandard.com/news-alibaba-group-to-help-ethiopia-set-up-first-ewtp-hubthe-second-in-africa (accessed on 25 November 2019).

76. World Bank. World Bank Open Data. Available online: https:/ / data.worldbank.org (accessed on 8 August 2021).

77. Blanchard, J.-M.F. Malaysia and China's MSRI: The Road to China was Taken Before the (Maritime Silk) Road was Built. In China's Maritime Silk Road Initiative and Southeast Asia: Dilemmas, Doubts, and Determination; Blanchard, J.-M.F., Ed.; Palgrave Macmillan: Singapore, 2019; pp. 95-131.

78. Liu, H.; Lim, G. The Political Economy of a Rising China in Southeast Asia: Malaysia's Response to the Belt and Road Initiative. J. Contemp. China 2019, 28, 216-231. [CrossRef]

79. Razak, N. Why Malaysia Supports China's Belt and Road. South China Morning Post. Available online: https://www.scmp. com/comment/insight-opinion/article/2094094/why-malaysia-supports-chinas-belt-and-road (accessed on 12 May 2017).

80. Naughton, B. Chinese Industrial Policy and the Digital Silk Road: The Case of Alibaba in Malaysia. Asia Policy 2020, 15, 23-39. [CrossRef]

81. Choong, H.W. Malaysia Gateway to a Digital Silk Road. China Daily. Available online: http:/ /www.chinadaily.com.cn/global/ 2019-10/17/content_37516267.htm (accessed on 17 October 2019).

82. New Straits Times. Digital Silk Road to Further Enhance China, Malaysia Cooperation. New Straits Times. Available online: https:/ / www.nst.com.my/business/2020/10/629078/digital-silk-road-further-enhance-china-malaysia-cooperation (accessed on 2 October 2020).

83. The Star. Future of the World Mapped Out, Says Wee. The Star. Available online: https://www.thestar.com.my/news/nation/20 17/05/15/future-of-the-world-mapped-out-says-wee (accessed on 15 May 2017). 
84. Azhar, K. Tech: Alibaba Cloud's City Brain Could Reduce KL Travel Time by 12\%. The Edge Markets. Available online: https:// www.theedgemarkets.com/article/tech-alibaba-clouds-city-brain-could-reduce-kl-travel-time-12 (accessed on 30 October 2019).

85. Li, L.; Cheng, T.F.; Kumar, P.P. Malaysia and Huawei to Deepen Ties with Cybersecurity Lab. Nikkei Asia. Available online: https:/ /asia.nikkei.com/Spotlight/Huawei-crackdown/Malaysia-and-Huawei-to-deepen-ties-with-cybersecurity-lab (accessed on 22 February 2021).

86. Wang, S.; Lahiri, T. A Future AI park in Malaysia Shows How Criticism is Changing China's Foreign Investment. Quartz. Available online: https: / / qz.com/1602194/an-ai-park-in-malaysia-shows-chinas-belt-and-road-is-evolving (accessed on 24 April 2019).

87. Freedom House. Freedom in the World-Malaysia (Various Years). Available online: https://freedomhouse.org/country/ malaysia/freedom-world/2021 (accessed on 26 July 2021).

88. Freedom House. Freedom on the Net-Malaysia (Various Years). Available online: https://freedomhouse.org/country/malaysia/ freedom-net/2020 (accessed on 1 August 2021).

89. TomTom, Traffic Index-Kuala Lumpur (Various Years). Available online: https://www.tomtom.com/en_gb/traffic-index/kualalumpur-traffic (accessed on 6 August 2021).

90. Fulton, J. China-UAE Relations in the Belt and Road Era. J. Arab. Stud. 2019, 9, 253-268. [CrossRef]

91. Fulton, J. Domestic Politics as Fuel for China's Maritime Silk Road Initiative: The Case of the Gulf Monarchies. J. Contemp. China 2020, 29, 175-190. [CrossRef]

92. Fulton, J. The Gulf Cooperation Council's 'Visions' of Maritime Silk Road Initiative Cooperation. In China's Maritime Silk Road Initiative, Africa, and the Middle East; Blanchard, J.-M.F., Ed.; Palgrave Macmillan: Singapore, 2021; Volume 227-254.

93. Triolo, P.; Allison, K.; Brown, C.; Broderick, K. The Digital Silk Road: Expanding China's Digital Footprint; Eurasia Group: New York, NY, USA, 2020.

94. Alarabiya News. UAE Telecom du Sees No Evidence of 'Security Holes,' in Huawei's 5G Technology. Available online: https: / / english.alarabiya.net/business/technology/2019/10/07/UAE-telecom-du-sees-no-evidence-of-security-holes-inHuawei-s-5G-technology (accessed on 7 October 2019).

95. Arabian Business. The Middle East's Role in China's Digital Silk Road. Available online: https:/ /www.arabianbusiness.com/ technology / 404802-the-middle-east-role-in-chinas-digital-silk-road (accessed on 26 September 2018).

96. Buller, A. Playing It Smart: How the UAE and Huawei Are Creating a City of the Future. Computerweekly.com. Available online: https:/ / www.computerweekly.com/news/450296414/Playing-it-smart-How-the-UAE-and-Huawei-are-creating-acity-of-the-future (accessed on 16 May 2016).

97. Freedom House. Freedom in the World-United Arab Emirates (Various Years). Available online: https://freedomhouse.org/ country/united-arab-emirates/freedom-world/2021 (accessed on 29 July 2021).

98. Gambrell, J. Virus Projects Renew Questions about UAE's Mass Surveillance. API. Available online: https://apnews.com/ article/virus-outbreak-health-ap-top-news-international-news-weekend-reads-e70e359d46391672a7a88f254cf9025b (accessed on 8 July 2020).

99. Freedom House. Freedom on the Net-United Arab Emirates (Various Years). Available online: https://freedomhouse.org/ country/united-arab-emirates/freedom-net/2020 (accessed on 5 August 2021).

100. United Nations Office on Drugs and Crime. Serious Assault: 2018. Available online: https://dataunodc.un.org/data/crime/ Serious\%20assault (accessed on 11 August 2021).

101. United Nations Office on Drugs and Crime. Robbery: 2018. Available online: https://dataunodc.un.org/data/crime/Robbery (accessed on 11 August 2021).

102. United Nations Office on Drugs and Crime. Burglary: 2018. Available online: https://dataunodc.un.org/data/crime/burglary (accessed on 11 August 2021).

103. Embassy of Hungary in Beijing. Political and Diplomatic Relations. Available online: https://peking.mfa.gov.hu/eng/page/ politikai-kapcsolatok (accessed on 24 July 2021).

104. Kong, T. Experience of Hungarian Economic Reform and China's economic reform (1979-1989): An Perspective of the History of Knowledge. In China and Hungary: 70 Years of Bilateral Relations in a Changing World; Chen, X., Ugrósdy, M., Eds.; China-CIEE Institute: Budapest, Hungary, 2019; pp. 14-39.

105. Center for European Policy Analysis. Hungary's Policy of “Opening to the East" Is More Than a Decade Old, but It Hasn't Delivered Chinese Investment. Available online: https:/ / cepa.org/hungarys-policy-of-opening-to-the-east-is-more-than-adecade-old-but-it-hasnt-delivered-much-chinese-investment/ (accessed on 8 March 2021).

106. Deutsche Welle. Why Is Hungary Siding with China Rather than the EU and NATO? Available online: https:/ /www.dw.com/ en/why-is-hungary-siding-with-china-rather-than-the-eu-and-nato/av-57832448 (accessed on 16 June 2021).

107. The Diplomat. Hungarian Policy Toward China Might Be Facing a Seismic Shift. Available online: https://thediplomat.com/20 21/06/hungarian-policy-toward-china-might-be-facing-a-seismic-shift/ (accessed on 9 June 2021).

108. Euronews. EU Agrees First Sanctions on China in More than 30 Years. Available online: https://www.euronews.com/2021/03/ 22/eu-foreign-ministers-to-discuss-sanctions-on-china-and-myanmar (accessed on 22 March 2021).

109. Hungary Today. Foreign Minister Slams EU Sanctions Against Myanmar, China as Pointless and Harmful. Available online: https:/ / hungarytoday.hu/foreign-minister-slams-eu-sanctions-against-myanmar-china (accessed on 22 March 2021). 
110. Empty Shell No More: China's Growing Footprint in Central and Eastern Europe; Karásková, I.; Bachulska, A.; Szunomár, A.; Vladisavljev, S. (Eds.) Association for International Affairs (AMO): Prague, Czech Republic, 2020. Available online: https: //chinaobservers.eu/wp-content/uploads/2020/04/CHOICE_Empty-shell-no-more.pdf (accessed on 23 August 2021).

111. The Diplomat. How Hungary's Path Leads to China's Belt and Road. Available online: https://thediplomat.com/2019/04/howhungarys-path-leads-to-chinas-belt-and-road/ (accessed on 11 April 2019).

112. Pavlicevic, D. A Power Shift Underway in Europe? China's Relationship with Central and Eastern Europe Under the Belt and Road Initiative. In Mapping China's 'One Belt One Road' Initiative; Xing, L., Ed.; Palgrave Macmillan: Cham, Switzerland, 2019; pp. 249-278.

113. Kavalski, E. China in Central and Eastern Europe: The unintended effects of identity narratives. Asia Eur. J. 2019, 17, 403-419. [CrossRef]

114. South China Morning Post. Hungary Is First in Europe to Sign Up for China's New Silk Road Plan. Available online: https: / / www.scmp.com/news/china/policies-politics/article/1818243/hungary-first-europe-sign-chinas-new-silk-road-plan (accessed on 7 June 2015).

115. Reuters. Hungary, China Sign Loan Deal for Budapest-Belgrade Chinese Rail Project. Available online: https://www.reuters. com/article/us-hungary-china-railway-loan-idUSKCN226123 (accessed on 24 April 2020).

116. China Observers. The Fight over Fudan: A Chinese University in Budapest Sparks Reckoning for Sino-Hungarian Relations. Available online: https:/ / chinaobservers.eu/the-fight-over-fudan-a-chinese-university-in-budapest-sparks-reckoning-for-sinohungarian-relations/ (accessed on 7 June 2021).

117. Radio Free Europe. The Underhanded Sale of Our Sovereignty: How China Became an Election Issue in Hungary. Available online: https:/ / www.rferl.org/a/hungary-china-orban-fudan-elections/31304764.html (accessed on 13 June 2021).

118. Daily News Hungary. Questionable Face Recognition Cameras to Be Installed in Hungary. Available online: https:// dailynewshungary.com/questionable-face-recognition-cameras-to-be-installed-in-hungary/ (accessed on 11 June 2021).

119. Freedom House. Freedom in the World-Hungary (Various Years). Available online: https://freedomhouse.org/country/ hungary / freedom-world/2021 (accessed on 1 August 2021).

120. WorldAtlas. Europe's 10 Most Surveilled Cities. Available online: https://www.worldatlas.com/articles/europe-s-10-mostsurveilled-cities.html (accessed on 1 January 2020).

121. Freedom House. Freedom on the Net-Hungary (Various Years). Available online: https://freedomhouse.org/country/hungary/ freedom-net/2020 (accessed on 8 August 2021).

122. Human Rights Watch. Hungary's Democracy Crisis Demands a European Response. Available online: https://www.hrw.org/ news/2019/09/26/hungarys-democracy-crisis-demands-european-response (accessed on 26 September 2019).

123. Human Rights Watch. Hungary: Editor's Sacking a Blow to Press Freedom. Available online: https://www.hrw.org/news/2020 /07/24/hungary-editors-sacking-blow-press-freedom (accessed on 26 June 2019).

124. OECD Better Life Index. Hungary. Available online: https://www.oecdbetterlifeindex.org/countries/hungary/ (accessed on 20 August 2021).

125. TomTom. Traffic Index-Hungary (Various Years). Available online: https://www.tomtom.com/en_gb/traffic-index/ranking/ ?country=HU (accessed on 7 August 2021).

126. European Road Safety Observatory. Road Safety Country Overview Hungary 2017. Available online: https://ec.europa.eu/ transport/road_safety/sites/default/files/erso-country-overview-2017-hungary_en.pdf (accessed on 23 August 2021).

127. Bogaards, M. De-democratization in Hungary: Diffusely defective democracy. Democratization 2018, 25, 1481-1499. [CrossRef]

128. Brookings. The Anatomy of Illiberal States: Assessing and Responding to Democratic Decline in Turkey and Central Europe; The Brookings Institution: Washington, DC, USA, 2019. 